\title{
КОМПЛЕКСЫ ЛАНТАНА, СОДЕРЖАЩИЕ ФРАГМЕНТ ПРОСТРАНСТВЕННО-ЗАТРУДНЁННОГО ФЕНОЛА, КАК ПЕРСПЕКТИВНЫЕ ЦИТОПРОТЕКТОРЫ
}

\author{
А.Б. Трусова', Е.А. Никитин ${ }^{2}$, Е.В. Латипов \\ ${ }^{1}$ Факультет наук о материалах, Московский государственный университет \\ им. М.В. Ломоносова, 119234, Россия, г. Москва, ул. Колмогорова, 1, с. 7-3. \\ ${ }^{2}$ Химический факультет, Московский государственный университет \\ им. М.В. Ломоносова, 119991, Россия, г. Москва, Ленинские горы, 1, с. 3. \\ ${ }^{3}$ ОРИМНС, Институт нанотехнологий и микроэлектроники РАН, \\ 119991, Россия, г. Москва, Ленинский проспект, 32А
}

DOI: 10.19163/MedChemRussia2021-2021-354_E-mail:alla.trusova.fnm@gmail.com

Окислительный стресс принимает участие в развитии тяжёлых заболеваний, включая онкологию. 2,6-Диалкилфенолы, миметики альфа-токоферола, обладают доказанным антиоксидантым и цитопротекторным действием [1].

Соединения РЗЭ проявляют значительную биологическую активность [2]. Препараты лантана («Эплан») обладают противовоспалительным и бактерицидным действием.

Целью данной работы является синтез комплексных соединений лантана, содержащих фрагмент 2,6-ди-трет-бутилфенола, как перспективных гибридных цитопротекторов. Карбоксилаты La (1-3) охарактеризованы методами ЯMP-, ИКспектроскопии, термогравиметрии и элементного анализа.

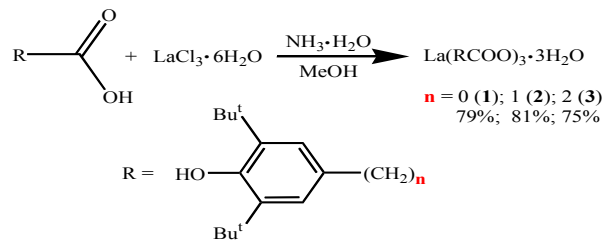

Эффективность соединений в роли антиоксидантов оценена в ходе ДФПГ- и CUPRAC-теста. Они являются умеренными ингибиторами окисления ненасыщенных жирных кислот.

Полученные результаты позволяют предложить исследуемую серию соединений для дальнейших испытаний в качестве перспективных гибридных цитопротекторов.

Работа выполнена при финансовой поддержке РФФИ (№19-33-90236).

\section{Литература}

[1] E. Nikitin, D. Shpakovsky, A. Pryakhin, T. Antonenko, V. Tyurin, A. Kazak, A. Ulyanov, V. Tafeenko, L. Aslanov, L. Dubova, E. Lysova, E. Shevtsova and E. Milaeva, Pharmacy \& Pharmacology International Journal. 2020, 8, 122-134.

[2] T. Antonenko, D. Shpakovsky, Yu. Gracheva, T. Balashova, A. Pushkarev, M. Bochkarev and E. Milaeva, Inorganica Chimica Acta. 2017, 455, 276-282. 